\title{
ISRAEL AND UNITED STATES CLAIM ON AL-QUDS: World History and International Law Perspective ${ }^{1}$
}

\author{
Achmad Zulfikar 1, Romi Maulidi 2, Waskito Wibowo 3 \\ ${ }^{1}$ Lecturer, Department of International Relations Universitas Muhammadiyah Yogyakarta \\ and Alumnae, Master of Law Universitas Muslim Indonesia \\ ${ }^{2}$ Alumnae, Department of International Relations Universitas Muhammadiyah \\ Yogyakarta \\ ${ }^{3}$ Alumnae, Department of Islamic Studies Universitas Islam Negeri Syarif \\ Hidayatullah Jakarta \\ Correspondent author: apa@kabarfikar.com
}

\begin{abstract}
This study aims to explore the impact of Israel claims on the Al-Quds since the surrender of territory by the British. Al-Quds in Arabic means "The Holy One" which is another name of the city of Jerusalem. In its development Israel received strong support from the United States. This strong support was demonstrated by President Donald Trump in a statement on 6 December 2017 that Jerusalem (Al-Quds) is the capital of Israel. The statement gets the pros and cons of various parties. This phenomenon attracts authors to explore the claims of Israel and the United States from the perspective of world history and international law. This paper uses qualitative descriptive method and data collection through literature review. The study concludes that Israel and the United States based on consensus of UN member states can not make unilateral claims against Jerusalem (Al-Quds) because it is not in line with historical and international law.
\end{abstract}

Keywords: Israel, United States, Al-Quds, World History, International Law

\section{$1 \quad$ INTRODUCTION}

Al-Quds comes from the Arabic meaning "The Holy One" which is another name for the city of Jerusalem, a city in the Middle East and one of the oldest cities in the world and is considered holy to the three major Abrahamic religions-Judaism, Christianity and Islam. Israelis and Palestinians are the two disputing sides in the city of Jerusalem, where Israel maintains its primary governmental institutions and the Palestine ultimately foresees it as its seat of power; however, neither claim is widely recognized internationally. The two countries dispute over the city has long gone and split the countries in the world into two blocs, between supporting the struggle of Palestinian or supporting Israel to defend its colonies. Due to the weak Palestinian position in this claim, Israel and its allies are attempting through various means to claim Al-Quds territory as its territory.

\footnotetext{
${ }^{1}$ Presented in International Conference "Al-Quds: History, Position and Sovereignty" organized by Universitas Darussalam Gontor, Indonesia and International Islamic University of Islamabad, Pakistan on February, $25^{\text {th }} 2018$.
} 
The Palestinian powerlessness to defend Al-Quds and the Israeli forces supported by its ally the United States has become the focus of the United Nations, even PostWorld War II, the United Nations in 1947 devised a plan for Al-Quds (Jerusalem). UN General Assembly resolution 181 (II) of 29 November 1947 on partition envisaged a demilitarized Jerusalem as a separate entity under the aegis of the United Nations Trusteeship Council, which would draft a statute for Jerusalem and appoint a Governor. A legislature would be elected by universal adult suffrage. This statute would remain in force for 10 years and would then be duly examined by the Trusteeship Council, with citizens' participation through a referendum.[1]

The ensuing hostilities prevented implementation of the resolution. Israel occupied the western sector of the Jerusalem area, and Jordan occupied the eastern sector, including the walled Old City. Thus, there came into existence a de facto division of Jerusalem. The UN General Assembly, however, by resolution 194 (III) of 11 December 1948, reaffirmed both the principle of internationalization and existing rights. The Arab States, refusing to recognize Israel, did not accept it. Israel also ignored the resolution and moved to extend its jurisdiction to that part of Jerusalem which it had occupied. On 23 January 1950, Israel declared Jerusalem its capital and established government agencies in the western part of the city. Jordan, for its part, moved to formalize its control of the Old City; however, Jordanian legislation indicated that this action did not prejudice the final settlement of the Palestinian issue.[2]

The above explanation shows that Israeli claims against Al-Quds always get opposition from the international society, one of them is United Nations. Israel's disregard for UN Resolution 1948 shows that the country has no goodwill in settling the Al-Quds territory dispute. On the one hand the Palestinian helplessness caused Jordan to become a guardian of Al-Quds. The dynamics in claims against Al-Quds has increased since the statement of U.S. President, Donald Trump on December 6, 2017. He asserted that Jerusalem (Al-Quds) is the capital of Israel. Although President Trump has a basis for consideration in his remarks, this has shaken the world's reputation and belief in the United States, which is the mediator for two state solutions for both Israeli and the Palestinians.

In addition, President Trump's statement reaps the pros and cons of various parties. Certainly Israel as the center of the statement welcomes the support of the United States that recognizes Jerusalem as Israel's capital, even the lobbies that Israel does to the EU and the countries deemed to be an ally of Israel. Countries incorporated in the Organization of Islamic Cooperation (OIC) led by several countries, one of which Indonesia strongly responds to the statement of President Trump and in a short time scheduled an emergency meeting in Turkey. The results of these OIC member states meetings resulted in a recommendation to bring the United States claim against Jerusalem (Al-Quds) to the United Nations. This has tamed the United States and Israel efforts against Al-Quds, the majority of United Nations member states in the General Assembly have objected to the claim and recommended efforts to ease the tensions caused by such unilateral claims. 
Based on the above exposure, this study aims to analyze from the world history that involves various countries in the process as well as the international law perspective in reveals the processes occurring in the Al-Quds dispute through agreements and treaties by both Israelis and Palestinians as the two legal entities that inhabit Al-Quds or generally known as Jerusalem. The discussion in this paper begins with a discussion of the history of Al-Quds from the perspective of three religions derived from the Prophet Abraham's lineage namely Judaism, Christianity and Islam. It is important to be explored to see the theological foundations of each religion to understand this claim more comprehensively. Then, further discussion on Israel and the United States claims on Al-Quds from world history perspective that will unravel chronologically Israel's claim to Al-Quds and the US involvement as an ally of Israel in time chronology recorded in the framework of world history. Finally, a discussion of the status of AlQuds in international law perspective. This discussion is important because every country in the world has been based on a stateless process under the legal framework, then the settlement of disputes and claims that are theological and subjective must be confronted by mutual agreement within the framework of applicable international law.

\section{METHODS}

This paper used qualitative research methods with data collection through literature review which sources from from journal, book and internet that related toward the issue of Al-Quds, including how Israel and the United States claim towards Al-Quds (Jerusalem) in the perspective of world history and international law.

\section{RESULTS AND DISCUSSION}

\subsection{History of Al-Quds from Judaism, Christianity and Islam Perspective}

The history of Al-Quds requires a comprehensive discussion, mainly from the perspective of Abrahamic/Samawi religions (Judaism, Christianity and Islam). The scriptures of the three religions have recorded their respective stories, including the story of Al-Quds in which there are three holy sites of the three religions. Mandour in the publication of Jerusalem: A Tale of A City states that Jerusalem plays an important role in three major religions: Judaism, Christianity, and Islam, as well as in a number of smaller religious groups (Figure 1). A large number of places have religious significance for these religions, among which the Temple Mount and its Western Wall (Figure 2) for Jews, the Church of the Holy Sepulcher (Figure 3) for Christians, and the Al-Aqsa Mosque (Figure 4) and Dome of the Rock for Muslims. Currently, there are 1.204 synagogues, 158 churches, and 73 mosques in Jerusalem. [3] This confirms that the perspective of all three religions is necessary for a comprehensive discussion. 

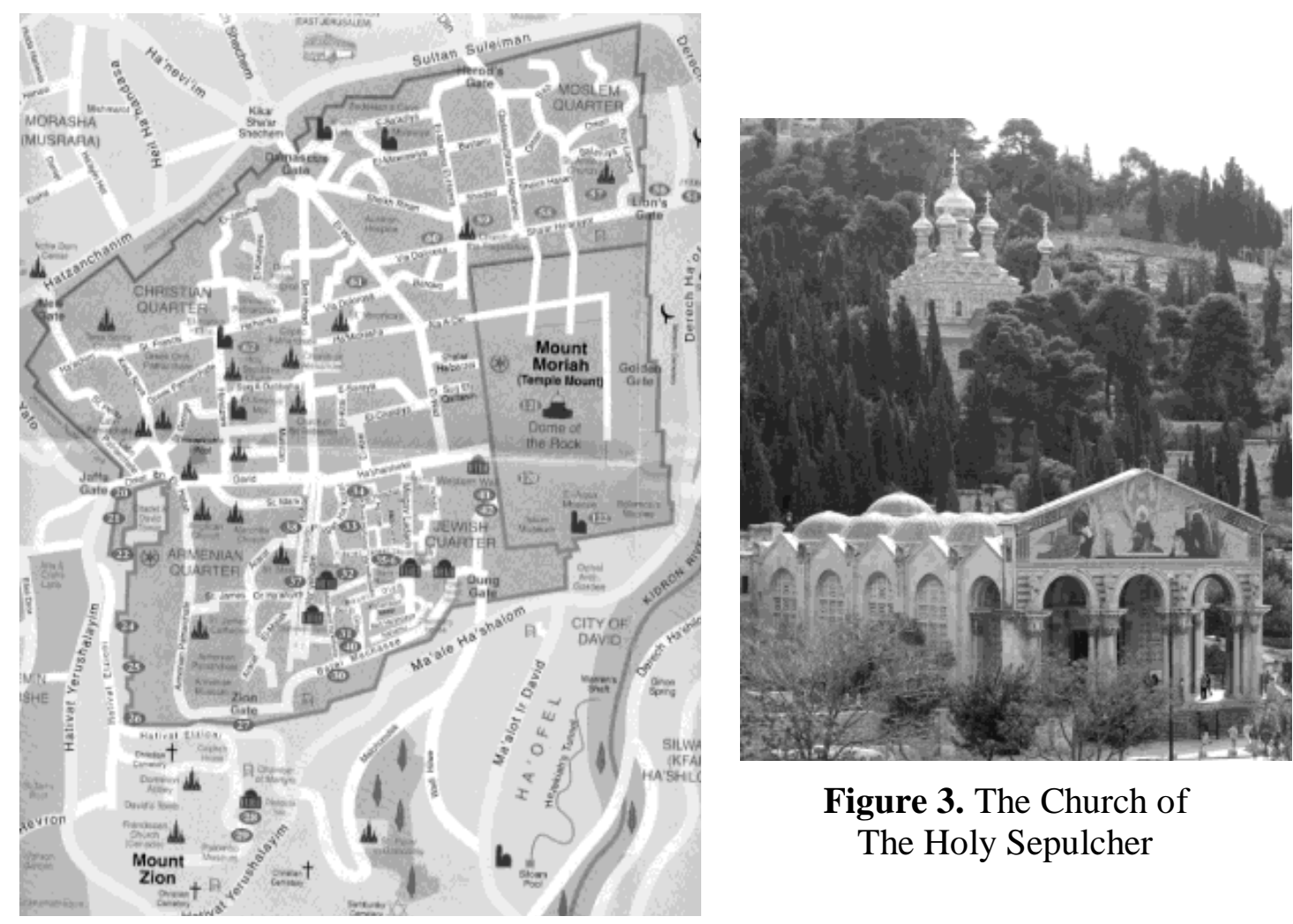

Figure 3. The Church of The Holy Sepulcher

Figure 1. The Map of Al-Quds (Jerusalem)

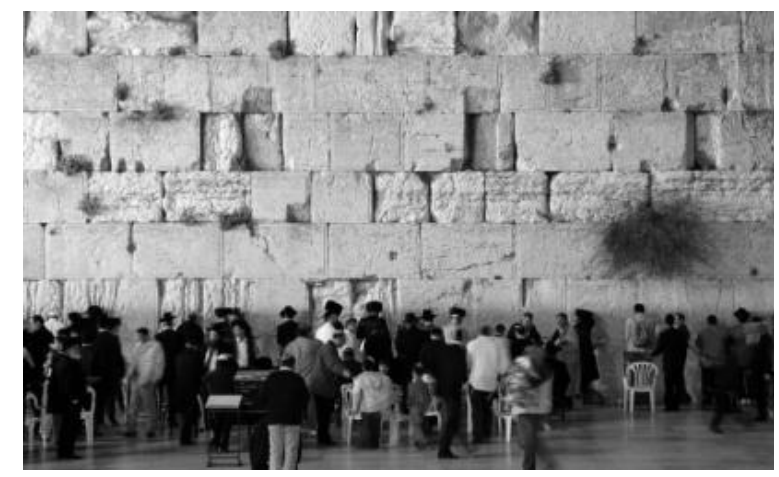

Figure 2. The Western Wall

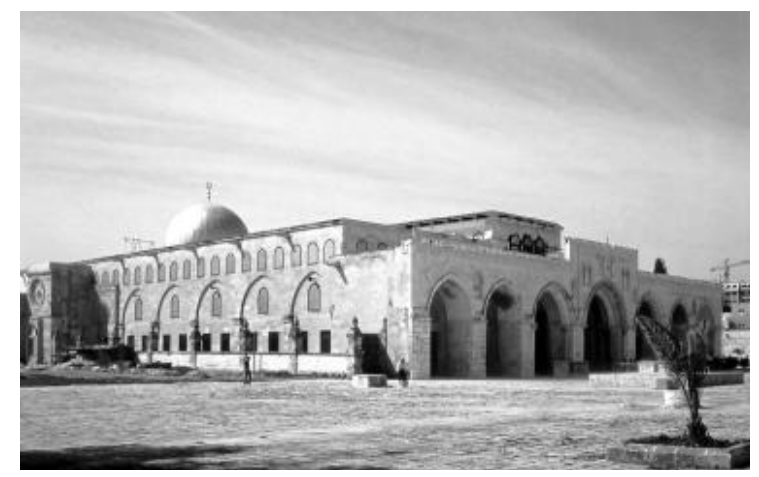

Figure 4. Al-Aqsa Mosque

\subsubsection{History of Al-Quds from Judaism Perspective}

Jerusalem (Al-Quds) was first referred as a name of city in Joshua 10 under the rule of Adoni-Zedek, as follows: He has founded his city on the holy mountain. The LORD loves the gates of Zion more than all the other dwellings of Jacob. Glorious things are said of you, city of God. (Ps 87:1-3) [4] Israel who affiliate themselves as the successor of the Jewish nation based his policy in expanding the region from the history of the Jewish nation that started from the time of Prophet Ibrahim. They believe that the migration of Israel began when Prophet Ibrahim came out of Babylon with his followers in 1900 BC to avoid undesirable things from King Namrud. By the people of Assyria and Kan'an they are referred to as Hebrews which in language have the meaning of the 
people who cross over. Until now, the Hebrew term is also often used to name the nation and language. [5] Theological study from Genesis 14:17-20: When he [Abraham] returned from defeating Chedor-laomer and the kings with him, the king of Sodom came out to meet him in the Valley of Shaveh, which is the Valley of the King. And King Melchizedek of Salem [Jerusalem] brought out bread and wine; he was a priest of God Most High. He blessed him, saying, "Blessed be Abraham of God Most High, Creator of heaven and earth. And blessed be God Most High, who has delivered your foes into your hand".

Furthermore, brief historical sketch of Jerusalem is gleaned from Montefiore's book: Jerusalem: The bibliography. The biblical history kicks into high ratio with David taking the stronghold by force (Montefiore, 2012:27): "Zion was said to be impregnable and how David captured it is a mystery'. He renamed the place 'The city of David'. It was a small place of some 15 acres but significant in terms of its location. [6] The appearance of the word 'Zion' was first in the Old Testament when King David established his kingdom in 1000-969 BC. The words 'Zion' in the Old Testament are mentioned 152 times. All point to the city of Jerusalem. More than half in 2 books, Isaiyah 46 times and in Mazmur 38 times. Others are scattered in various books. Zion is later identified with the holy city of Jerusalem itself.

Jews first entered the Jerusalem area in the time of David. Earlier the initiation of the state of Israel was started by Syaul (Thalut) in 1025 BC. He gathered the tribes of all the Jews to fight against the king of Jalut (Goliath). One of Syaul's troops was a young man named David who would lead the people of Israel after the Thalut. This also makes the Palestinian territory also under David's leadership. $\mathrm{He}$ is also regarded as the founder of the realm of the Israelites in Palestine territory.[7]

However, David and his successors enhanced Jerusalem's credentials even further by transforming the city into the most important national and religious site for Jews. Psalms 48, 122, 125, and 126, for example, describe the spiritual dimension of the city and its unique religious status. Traditions associating the city with Abraham (Genesis 14:18-20; 22:1-19) crystallized with the purpose of demonstrating the Jewish people's ties to the city from earliest times. So successful were these efforts that Jerusalem became known as the City of David and soon became inextricably intertwined with Israel's present and future. As a result, Mount Zion replaced Mount Sinai as the focus of Jewish attention (Japhet 1999, 3-8; Zakovitch 1999, 16-35). [8]

After the leadership of David and Solomon who ruled the Palestinian territories for about 80 years, since 923 BC Solomon's kingdom split into two states. First, the Kingdom of Jehuza (Judah) in the South with its capital Jerusalem (Al-Quds). The Kingdom was led by Rehoboam ibn Solomon. He was baptized and supported by two tribes of the Israelites, Jehuza and Benjamin, who lived in the South and around Jerusalem. But in other areas, Syakim or Syakin does not want to pay him as king of the Israelites, because of his rudeness and for threatening the people there, if he does not want to bribe him. The ten tribes of the Israel who were there refused to pledge and 
instead they baptized Rehoboam, from the tribe of Ephraem (one of the tribes of Israel) and this is the second kingdom of the Israel which is in the north.[9]

The books of Kings and Samuel (and Deuteronomy, which is closely related to their outlook) place enormous significance on the establishment of Jerusalem as the Jewish nation's sole ritual center. According to the views promoted by these books, sacrifice is not legitimate in any other location, even if intended for the God of Israel. This is closely connected with the House of David's desire to establish in perpetuity the political hegemony of both its capital and its dynasty. Pointed expression is given to this conception, which ties together the city, the Temple, and the House of David, in Solomon's prayer at the dedication of the Temple. There he cites the words of God: "Since the day that I brought forth my people Israel out of Egypt, I chose no city out of all the tribes of Israel to build a house, that my name might be therein; but I chose David to be over my people Israel' (Kings, 8:16).

Based on the above explanation it can be understood that the expansion of Judaism as a doctrine begins from followers of the Prophet Ibrahim, the Israelites who theologically shows that the successful of the Prophet Abraham is a gift from God as revealed in one quote verses Genesis. Then, the journey of the Israel entered the area of Jerusalem when David was included in the entourage commanded by Syaul (Thalut) to fight the King Jalut (Goliath). After winning the war against King Jalut, when David was considered to be in command. He became the leader of the Israelites and was considered the founder of the kingdom of the Israelites. Then the leadership continued from David to the continuation that further strengthened the identity of the Israelites in Jerusalem. In the end after the 80 years of David and Solomon's rule in Jerusalem land there was a power struggle that divided the territory among the groups of the Israelites.

\subsubsection{Al-Quds History from Christianity Perspective}

Al-Quds (Jerusalem) in Christianity's doctrine is quite famous. As in the Old Testament and the New Testament, there are many prophetic stories that are not very different from those believed by the Jews [10]. It is narrated that Jesus is the son of Mary, a Jew is the founder of the Messianic movement in Judaism, Jesus has proclaimed the kingdom of God that will come from the beginning of his missionary activities. His journey to Jerusalem for Easter was probably because he expected the kingdom to begin in Jerusalem. But once in Jerusalem, he was later crucified by the Roman.[11] The followers of Jesus consider this city (Jerusalem) to be the site of the marvelous miracle of redemption of his reincarnation, and as the place of his promised return in the gospel. From Jerusalem also, the first apostles proclaimed the Gospel, the good news of the coming kingdom of God, to be escorted with the return of his son, who was crucified. and rise up the messiah.[12]

When period of the Roman Emperor Constantinople who had embraced Christianity in 325 AD. In Al-Quds (Jerusalem) built the church of the Holy Sepulcher as the greatest church. At the top of Mount Zaitun also built the church of Heaven and 
in the city of Bethlehem also built the church of Doomsday. As for the Jews at that time especially the traders had spread to European countries. As for the Palestinians themselves, the Jews are urged by the development of the Nazarene which is supported directly by the Christian rulers. Therefore, Jews wherever they are, including in Europe still hinder the Christians. The Jews or the Israel rejected their last prophet by accusing him of witchcraft and trying to kill Jesus. The Israel did so because it was assumed that the Christians had destroyed the divine principles and the Talmudic about the Jewish greatness as a chosen nation.[13]

Based on the above explanation it can be understood that Christianity doctrine still provide recognition of the stories believed by the Judaism doctrine. Al-Quds (Jerusalem) in Christianity is a holy place, where Jesus is believed to be the redeemer of the sin crucified and resurrected. However, the conflict between Judaism and Christianity occurred during the rule of the Roman empire, where the Roman Emperor as Christianity urged the existence of the Jews and established churches to mark Jerusalem as his territory at that time.

\subsubsection{History of Al-Quds from Islam Perspective}

Al-Quds for the Islam believers is a special place. Theologically, Al-Quds is believed to be the foundation of the Prophet Muhammad during the journey of Isra' Mi'raj, upon receiving revelation from Allah SWT.[14] Isra' means a night trip from the Grand Mosque (Makkah) to the Aqsa Mosque (Al-Quds/Jerusalem) and Mi'raj means up into the sky. The story of Isra' Mi'raj and the message from Allah SWT to perform the prayers made the Aqsa Mosque located in Al-Quds became the first qiblah for Muslims. God's message is contained in the Surah of Al-Isra verse 1, as mentioned:

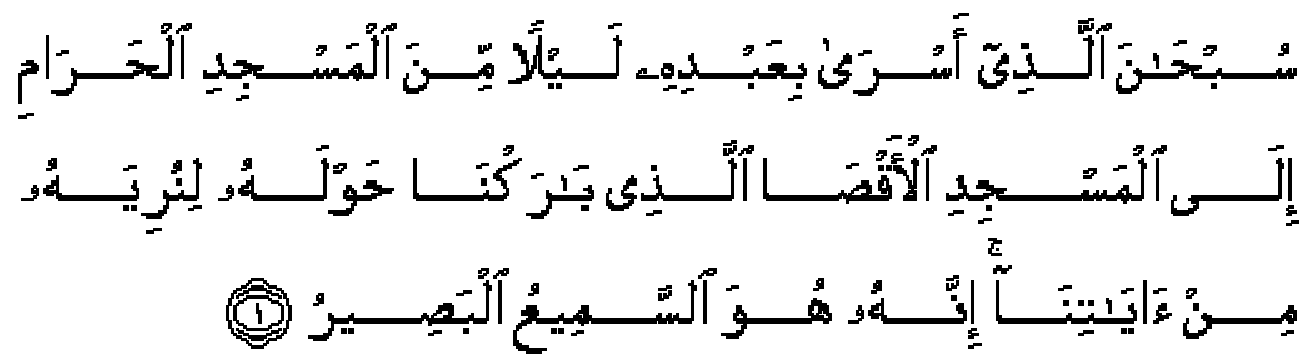

Meaning (Sahih International): Exalted is He who took His Servant by night from alMasjid al-Haram to al-Masjid al- Aqsa, whose surroundings We have blessed, to show him of Our signs. Indeed, He is the Hearing, the Seeing. [15]

Although in the end, the qiblah of Muslims was transferred to the Ka'bah, but the Aqsa Mosque is still mentioned in Surat al-Baqarah verse 144, as mentioned: 

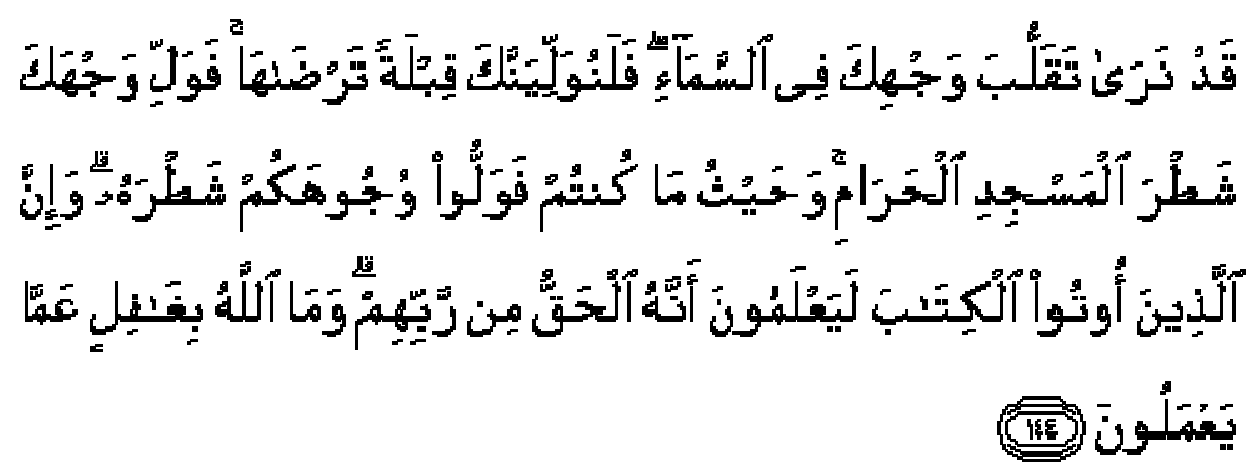

Meaning (Sahih International): We have certainly seen the turning of your face, [O Muhammad], toward the heaven, and We will surely turn you to a qiblah with which you will be pleased. So turn your face toward al-Masjid al-Haram. And wherever you [believers] are, turn your faces toward it [in prayer]. Indeed, those who have been given the Scripture well know that it is the truth from their Lord. And Allah is not unaware of what they do. [16]

Abdullah Yusuf Ali asserts that the direction towards the Ka'bah as a final provision has shown the validity of the relationship between Islam and the origins of the religious construction of Ibrahim's monotheism [17]. Likewise, Islam as the last shari'ah recognizes the existence and story of previous Prophets in its own version, most of whom are of course from the Israel. So that Muslims also trust the sites of historical heritage located in the area of Jerusalem. One example is the belief in the existence of the tomb of Prophet David who was in the ancient cemetery on Mount Zion as the Jews and Christians believe [18].

This position is also confirmed by the Prophet Muhammad contained in the book of Sahih Bukhari number 1115 and Shahih Muslim number 1397.

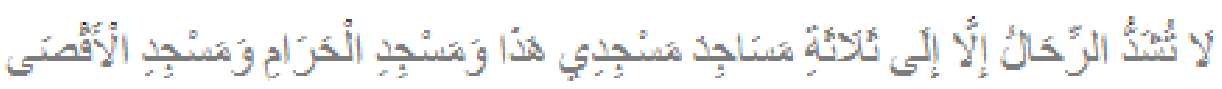

Meaning: Do not you travel long distances except to the three mosques: my mosque (Masjid Nabawi), Al Haram Mosque, and Al Aqsa Mosque.

Jerusalem has also been contested by Muslims. This story began when the third Khulafaur Rashidin, Umar bin Khattab, signed an agreement with Christian Patriakh Monofisit Sophronius to convince him that the holy sites and Christians of Jerusalem will be protected under Muslim rule. In addition to the peaceful surrender, it was the surrender of some of the city's power to the Christians, although in principle it remained under the rule of the Muslim governor for the city, Amr ibn Ash [19]. After that, Jerusalem experienced several seizures between various groups. After being under the rule of Umayyad and Abbasid dynasties, it was subsequently replaced by Muslim forces and Christian forces in the crusade. Until the last was under the Ottoman Turks.

Based on the above explanation it can be understood that Islam also has a theological foundation of Al-Quds in which there is the Aqsa Mosque which witnesses the journey of Isra' Mi'raj and the establishment of the Aqsa Mosque as the first qiblah of Muslims. Theological description of Islam towards Al-Quds (Aqsa Mosque) is 
contained in Al-Qur'an, surah Al-Isra verse 1 and the transfer of the qiblah position from the Aqsa Mosque to the Ka'bah in the Al-Qur'an, surah Al-Baqarah verse 114. Islam also has a historical connection and also share the understanding that the tomb of Prophet David is in the ancient cemetery on Mount Zion, it is also believed by the Judaism and Christianity. In its development, Islam also took part in the struggle for power in Jerusalem, this occurred at the time of Caliphate, Umar bin Khattab who became 'ruler' in Jerusalem and provide assurance to Jews and Christians to keep normal activities under the leadership of the Muslim Governor. Although in the end there must be a Crusade that made the territory of Jerusalem under the Ottoman Turks at that time.

The history of Al-Quds viewed from the perspective of Judaism, Christianity and Islam shows the link between the theological studies of each doctrine and the apparent historical journey. Starting from the story of Prophet Ibrahim. who brought the Israel to the hijrah that became the forerunners of the Jews who brought the Judaism doctrine. Later, the Israelites entered Jerusalem after the war between David and King Jalut, followed by the leadership of David and his successor to Solomon who occupied the land of Jerusalem for 80 years. After the leadership of David and Solomon, the land of Jerusalem was subsequently divided into two large areas contested by his own people, the Israelites. Entering Christianity's doctrine, the history of Al-Quds as a holy place, where Jesus was crucified by an instigated Jew who in Christianity's doctrine was the moment of Jesus' redemption to be resurrected. This event had an impact on the relations of the Jews and Christians during the rule of the Roman empire, where they were expelled from the land.

The history of Al-Quds continues in the perspective of Islamic doctrine, the existence of this region as a special place, where this area became a foothold before Isra' Mi'raj to receive the revelation of the command of prayer and the Aqsa Mosque in Al-Quds became the first qiblah of the Islam believers. Until the seizure of power is also not avoided to defend Al-Quds under the leadership of the Caliphate, Umar bin Khattab who actually became mediators of the conflict that time it occurred in Al-Quds. The leadership of Muslim Governor in Al-Quds guarantees both Jews and Christians to stay normal without intervention. Despite having a peaceful life in Jerusalem, the Crusades put the region back in turmoil, though it remained under Ottoman leadership. Based on these explanations, it can be understood that the history of Al-Quds is filled with the dynamics of three interrelated religious doctrine and confirm each other. The struggle for power also colored the history of Al-Quds. The history of Al-Quds in the contemporary era will be discussed further.

\subsection{Al-Quds from World History Perspective}

The history of Al-Quds as previously described from a theological perspective shows appreciation for this place. The doctrine of Judaism make Jerusalem a City of God, as well as the privileges that Christianity teaches that Jesus event was crucified and resurrected as penance until the Islam that made the Aqsa Mosque located in Al- 
Quds region as the first qiblah of Muslims. So it is appropriate to say that the history of Al-Quds (Jerusalem) is the world history and the history of the civilization of the world's major religions adopted nearly $2 / 3$ of the world's population.

Al-Quds as discussed in the previous section is also inseparable from the contested territory and leads to conflicts that become historical, present, and even in the future. Conflict that occurs because the city is ogled by many dynasties, caliphates, and the great empire of the world in the past. In the present time, Al-Quds is again in a vortex of conflict that is a continuous claim from Israel to Jerusalem and supported by United States as his ally.

Al-Quds (Jerusalem) is the one of the oldest cities in history. Starting from the Proto period of Kana'an around 4500-3500 BC, followed by the Neo-Babylonian period, the Roman period, the Byzantine period, the Rashidun, Umayyad and Abbasid periods, followed by the Fatimid period until the Ottoman period decline and the city's handover into the England mandate in 1917. The city was once destroyed twice, encircled 23 times, attacked 52 times, and contested 44 times.[20]

Jerusalem, City of David

According to the Old Testament, David, king for the kingdoms of Judah and Israel, conquered Jerusalem from the Jebusites around 1000 BC. David then moved his government to Jerusalem, making it the capital and religious center of his empire. The Bible says that David's son, Solomon, built the first temple for Yahweh, the God of Israel. Jerusalem became the center of Judaism.

\section{Under Persian rule}

The King of Neo-Babylon, Nebuchadnezzar II conquered Jerusalem in 597 BC and again in $586 \mathrm{BC}$, as the Bible says. He brought King Jehoiakim and Jewish upper class into custody, sent them to Babylon and destroyed the temple. After the Persian king Cyrus the Great captured Babylon, he allowed exiled Jews to return to Jerusalem and rebuild their temples.

Under Roman and Byzantine rule

From 63 AD, Jerusalem was under Roman rule. The resistance movement was quickly formed, so in the year $66 \mathrm{AD}$ broke out the First Jewish-Roman war. The war ended 4 years later, with Roman victory and the destruction of the temple in Jerusalem. The Romans and the Byzantines ruled Palestine for about six hundred years.

Conquest by Arabs

During the Islamic conquest of Syria, the Muslim army also arrived in Palestine. At the behest of Caliphate, Umar, Jerusalem was besieged and ruled by the Arabs in 637 AD. In the era of the following Muslim governments, various, mutually hostile and divided religious leaders led the city. Jerusalem was often surrounded and changed hands several times.

Crusade

From $1070 \mathrm{AD}$ onward, the Muslim rulers increasingly push the position of Christian world. Pope Urbanus II finally called for the Crusades. A total of 5 Crusades 
took place to conquer Jerusalem within 200 years. In 1244 AD, however, the Crusaders eventually lost control of the city and once again fell under Muslim rule.

Ottoman and British rule

After the conquest of Egypt and Arabia by Ottomans, Jerusalem became the center of Ottoman empire in $1535 \mathrm{AD}$. In the first decade of Ottoman rule, the city saw a clear resurrection. But the Caliphate collapsed after the defeat of the central bloc in the first world war and its territory was divided by the war-winning countries joined in the allied bloc. With an allied victory against the Ottomans in 1917, the Palestinians fell under British rule and then Jerusalem changed hands to England without a fight. After that mandate, Arabs and Jews alike are trying to conquer this city. But the minority in the city, like Christians, loves a city that is open to all three religions. This opinion was given by the Europeans at the United Nations, who in partitioning the Palestinians into Arab and Jewish countries, declared that Jerusalem would be an internationally managed city, but in the projected Arab country.

A Divided city

After World War II, England handed over the Palestinian mandate. The United Nations elected a division in the country to form a home for Holocaust survivors. Some Arab countries then fought against Israel and conquered Jerusalem. Until 1967, the city was divided into western Israel and eastern Jordan. Even before the partition came into force on May 14, 1948, fighting between Jews and Arabs took place in the city. On May 28, the Jews in the Old City surrendered but the New City remained in the hands of the Jews. The Old City and all the territories held by the Arab Legion - the quadrant that marked East Jerusalem - was annexed by Jordan in April 1949. The newly formed state of Israel responded by defending its territory and on 14 December 1949, the New City of Jerusalem was declared Israel's capital, a politically motivated goal symbolizing Jewish history and power. (Under the ongoing UN resolution that debates the city's status, Israel then makes Tel Aviv its capital).[21]

\section{East Jerusalem returns to Israel}

In 1967, Israel launched the Six Day War against Egypt, Jordan and Syria. Israel controls the Sinai, the Gaza Strip, the West Bank, the Golan Heights and East Jerusalem. Israeli paratroopers gained access to the Old City and stood at the Wailing Wall for the first time since 1949. East Jerusalem was not officially annexed, but integrated into government. East Jerusalem residents are offered ordinary Israeli citizenship but almost all choose to keep their status as Jordanians. Israel then moved many Arabs out of the Old City but still guaranteed access to holy sites for Muslims and Christians. In July 1980, the Israeli parliament approved a law that affirmed Jerusalem as the historic capital and divided the country for all Jews but the successive position of the Israeli government is to keep Tel Aviv as the capital (as recognized by the UN) while threatening to "declared". With suburban and residential development in the territory previously held by Jordan, Jerusalem has become Israel's largest city. But the dispute between Arabs and Jews still continues.[22] 


\section{United Nations Resolution}

The controversy surrounding the status of Jerusalem as a capital city for Muslims or Jews has been the subject of the United Nations resolution. Jerusalem was discussed as the third command of Resolution 181 in 1947, which dealt with the city as a separate entity (corpus separatum). A plan was submitted to the United Nations on 4 April 1950 which outlines the management of the holy sites, which the UN should control through a legislature: (1) Jerusalem must be divided into two sectors: one run by Arabs and the other by Jews; (2) Jerusalem must be an unarmed and neutral territory and no one has the right to declare as capital city and (3) Public councils must be established from all regions, and special systems shall be established to defend the holy places. Jerusalem is still disputed between Israel and the Palestinians. In 1980, Israel declared the entire city "the eternal and inseparable capital". After Jordan submitted its claim to the West Bank and East Jerusalem in 1988, the state of Palestine was proclaimed. Palestine also states in theory, Jerusalem as its capital.

\subsection{Status of Al-Quds in International Law Perspective}

The position of Al-Quds as one of the oldest cities in the world and is considered holy to the three major Abrahamic religions-Judaism, Christianity and Islam is an irrefutable historical fact. Nevertheless, the claims of various parties, mainly from Israel with the support of the United States against Al-Quds are certainly unwarranted unilateral claims. It is therefore important to place Al-Quds in the perspective of international law. The status of Al-Quds in the international law perspective can provide legal certainty and can also provide an explanation that has a constitutional basis on the status of a region.

Al-Quds has long been the dispute of various parties. However, the foundation that is used does not yet have international law that has codification and written as it is today. The law of antiquity was more focused on the occupation of an area and the winner of the war got everything, including the region. Entering the era of the World War I, Ottoman Turks who controlled the Jerusalem area lost the war from the allied bloc, one of whose members was the British who got the rights to the territory of Jerusalem. Then after the World War II, England handed over the mandate of the Jerusalem territory to the United Nations for a formal path.

The result of this formal submission is UN General Assembly resolution 181 (II) of 29 November 1947 on partition envisaged a demilitarized Jerusalem as a separate entity under the aegis of the United Nations Trusteeship Council, which would draft a statute for Jerusalem and appoint a Governor. A legislature would be elected by universal adult suffrage. This statute would remain in force for 10 years and would then be duly examined by the Trusteeship Council, with citizens' participation through a referendum. The ensuing hostilities prevented implementation of the resolution. Israel occupied the western sector of the Jerusalem area, and Jordan occupied the eastern 
sector, including the walled Old City. Thus, there came into existence a de facto division of Jerusalem. [23]

The UN General Assembly, however, by resolution 194 (III) of 11 December 1948, reaffirmed both the principle of internationalization and existing rights. The Arab States, refusing to

recognize Israel, did not accept it. Israel also ignored the resolution and moved to extend its jurisdiction to that part of Jerusalem which it had occupied. On 23 January 1950, Israel declared Jerusalem its capital and established government agencies in the western part of the city. Jordan, for its part, moved to formalize its control of the Old City; however, Jordanian legislation indicated that this action did not prejudice the final settlement of the Palestinian issue. The war of June 1967 radically changed that situation. As a result of the war, Israel occupied East Jerusalem and the West Bank. [24]

Since then, a number of demographic and physical changes have been introduced, and both the General Assembly and the Security Council, in several resolutions, have declared invalid the measures taken by Israel to change the status of Jerusalem. Security Council resolution 252 (1968) in particular is explicit in this regard. In it, the Council considered "that all legislative and administrative measures and actions taken by Israel, including expropriation of land and properties thereon, which tend to change the legal status of Jerusalem are invalid and cannot change that status". Israel was urgently called upon "to rescind all such measures already taken and to desist forthwith from taking any further action which tend to change the status of Jerusalem". The Security Council has reaffirmed these two positions many times. [25]

When Israel took steps to make a united Jerusalem its capital, the Security Council on 30 June 1980 adopted resolution 476 (1980) urgently calling on Israel, the occupying Power, to abide by this and previous Security Council resolutions and to desist forthwith from persisting in the policy and measures affecting the character and status of the Holy City of Jerusalem.After Israel's non-compliance with the resolution, the Council, on 20 August, adopted resolution 478 (1980), in which it reiterated its position that all actions altering the status of the city were null and void, and called upon States that had established diplomatic missions in Jerusalem to withdraw them. The General Assembly also considered Israel's action to be a violation of international law that did not affect the continued applicability of the Fourth Geneva Convention. This understanding, affirmed by the Assembly in December 1980, has been reaffirmed in subsequent years. [26]

During the 1980s, United Nations resolutions dealt with the Jerusalem issue in the wider context of the inadmissibility of the acquisition of territory by force and the applicability of the Fourth Geneva Convention to the Palestinian territory occupied by Israel since 1967. East Jerusalem has been considered, by both the General Assembly and the Security Council, as part of the occupied Palestinian territory. As the international community and in particular the Security Council continued to follow with concern developments affecting the question of Palestine, an important action was taken by the Council through resolution 672, adopted on 12 October 1990 following the 
violence that took place in Jerusalem at Haram Al-Sharif, where the Al-Aqsa mosque, the third holiest shrine in Islam, is situated. The Council, after condemning "especially the acts of violence committed by the Israeli security forces resulting in injuries and loss of human life", called upon Israel "to abide scrupulously by its legal obligations and responsibilities under the Geneva Convention relative to the Protection of Civilian Persons in Time of War, of 12 August 1949, which is applicable to all the territories occupied by Israel since 1967”. [27]

The applicability of the Fourth Geneva Convention to Jerusalem was re a ff i rmed by the Security Council on 20 December 1990, when it expressed grave concern at the deteriorating situation in "all the Palestinian territories occupied by Israel since 1967, including Jerusalem", and called on Israel to abide by it. Since 1997, the tenth emergency special session of the UN General Assembly has been resumed several times. At the resumed emergency session held in Febru a ry 1999, the Assembly affirmed its support for the Middle East peace process on the basis of the relevant Security Council resolutions and for the principle of land for peace. Recalling its relevant resolutions, including resolution 181 (II) (the Partition Plan) and those of the Security Council, the Assembly reaffirmed that the international society, through the United Nations, has a legitimate interest in the question of the city of Jerusalem and the protection of its unique spiritual and religious dimension. It further reaffirmed the continued invalidity of all actions taken by Israel, the occupying Power, that have altered or purported to alter the character, legal status and demographic composition of Jerusalem. [28]

In May 1999, the Israeli Government approved a plan to enlarg e the area of the settlement of "Maaleh Adumim", east of Jerusalem, by over 1.300 hectares $(3,250$ acres), forming a continuous strip of settlements. According to the 1999 report of the Palestinian Rights Committee submitted to the $54^{\text {th }}$ session of the General Assembly, once completed, the number of settler households in the settlement would increase by an estimated 25 per cent. The UN General Assembly, in a resolution adopted on 9 February 1999, reiterated that all legislative and administrative measures and actions taken by Israel, the occupying Power, which had altered or purported to alter the character, legal status and demographic composition of Occupied East Jerusalem and the rest of the occupied Palestinian territory, were null and void and had no validity whatsoever. [29]

The UN General Assembly revisited the question of Jerusalem at its $55^{\text {th }}$ session. In a resolution adopted on 1 December 2000, the Assembly determined that the decision of Israel to impose its laws, jurisdiction and administration on the Holy City of Jerusalem was illegal and, therefore, null and void. The Assembly also deplored the transfer by some States of their diplomatic missions to Jerusalem in violation of Security Council resolution 478 (1980). These statements and resolutions, as well as many others adopted by United Nations bodies, international organizations, nongovernmental organizations and religious groups, demonstrate the continuing determination of the international community to remain involved in the future of Jerusalem. They also show the great concern over the delicate status of the peace 
process and the unanimous desire that no actions be taken that could jeopardize that process. [30]

The dynamics in Al-Quds status resumed when President Trump on December, 62017 declared Al-Quds (Jerusalem) as the capital ciry of Israel. The official website of the U.S. government www.whitehouse.gov in quotation of its statement as follows: "In 1995, Congress adopted the Jerusalem Embassy Act, urging the federal government to relocate the American embassy to Jerusalem and to recognize that that city - and so importantly - is Israel's capital. This act passed Congress by an overwhelming bipartisan majority and was reaffirmed by a unanimous vote of the Senate only six months ago; Yet, for over 20 years, every previous American president has exercised the law's waiver, refusing to move the U.S. embassy to Jerusalem or to recognize Jerusalem as Israel's capital city". [31]

The above statement raises the pros and cons of various parties. Israel as a central figure welcomes the support of the United States that recognizes Jerusalem as Israel's capital, even the lobbies that Israel does to the European Union and the countries deemed to be an ally of Israel. Meanwhile, the countries joined in the Organization of Islamic Cooperation (OIC) led by several countries, one of which Indonesia strongly responds to the statement of President Trump and in a short time scheduled an emergency. Turkish President Recep Tayyip Erdogan called an extraordinary summit of the Organisation of Islamic Cooperation (OIC) in December, 13 2017, following Trump's decision on Jerusalem. During the meeting in Istanbul, the 57-member group denounced Trump's move as "null and void" and called on the United Nations to "end the Israeli occupation" of Palestine. Muslim leaders warned that Trump's administration will be liable for "all the consequences of not retracting from this illegal decision".[32]

Turkey's Hurriyet newspaper reported that Erdogan launch initiatives at the United Nations to have Washington's "disgraceful" decision annulled. He stated, "As a country, we are determined to do our bit on this issue. We will wash the dirty laundry of those who breach international law". He also stated, "We will work to annul this unlawful decision, first in the Security Council and then in the UN General Assembly if it is vetoed there". He added that Ankara will encourage other countries to recognise the Palestinian state, "Right now, 137 countries in the world recognise the Palestinian state. God willing, this number will further increase with our efforts".[33] 


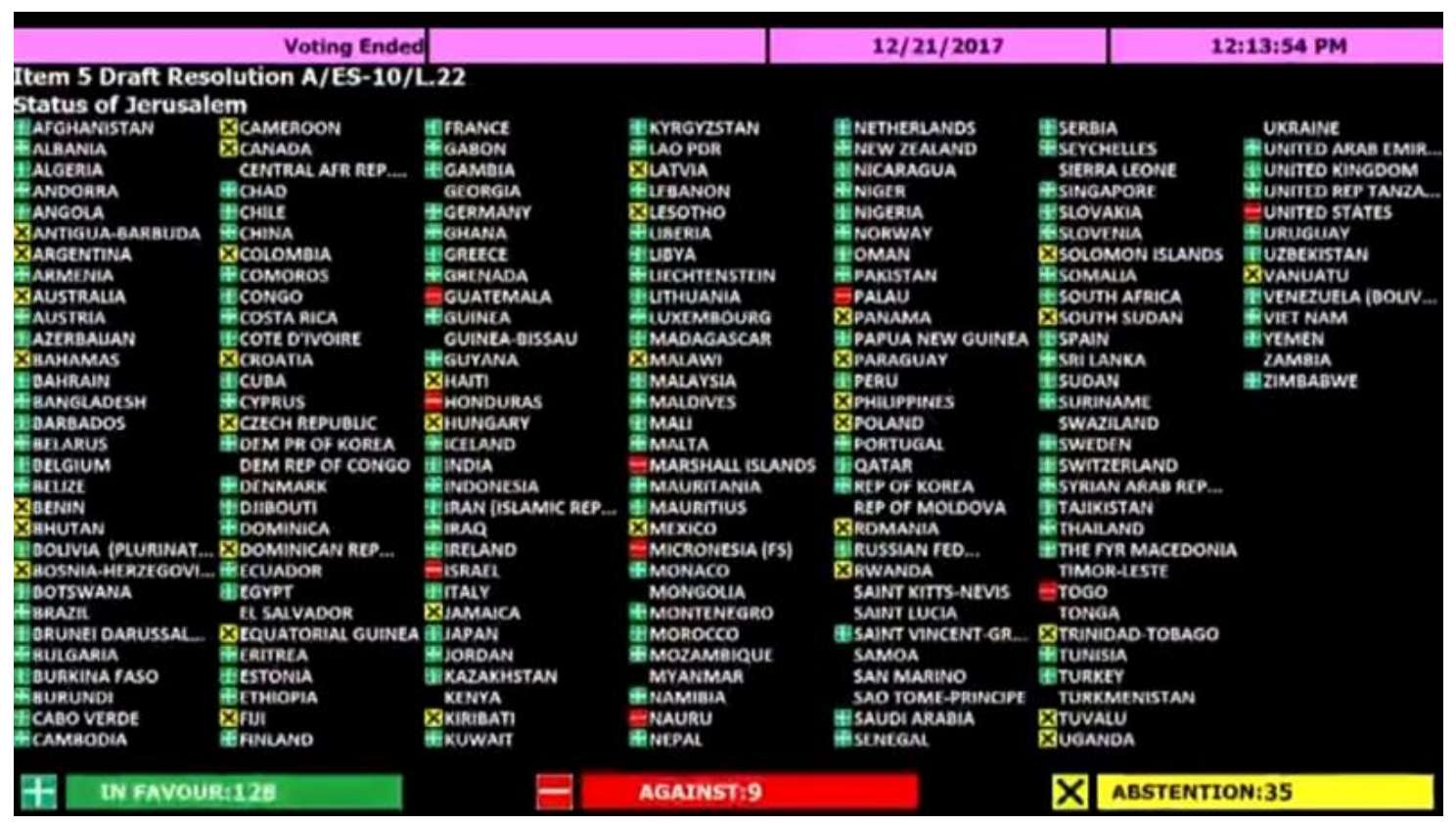

Figure 5. UN Jerusalem resolution: How each country voted [34]

Pressure from OIC member states succeeded in bringing the issue of U. S. claim to the United Nations meeting so that an emergency session was held. The UN General Assembly has decisively backed a resolution effectively calling on the US to withdraw its recognition of Jerusalem as the capital of Israel. The text says that any decisions regarding the status of the city are "null and void" and must be cancelled. The nonbinding resolution was approved by 128 states, with 35 abstaining and nine others voting against in 21 December 2017. The nine who voted against the resolution were the U.S., Israel, Guatemala, Honduras, the Marshall Islands, Micronesia, Nauru, Palau and Togo Among the 35 abstaining were Canada and Mexico. Those voting in favour included the other four permanent members of the UN Security Council (China, France, Russia and the UK) as well as key US allies in the Muslim world. There were 21 countries who did not turn up for the vote. [35]

Based on the above explanation shows that the Israeli and U.S. claims to Jerusalem to get strict surveilance from the international society through various institutions of international cooperation. From the establishment of UN Resolution in 1947 to the resistance to the U.S. claim on Jerusalem's as Israel capital by 2017. This shows that for 70 years Israel's efforts to seize control of the Palestinian territories in Jerusalem have been opposed by the international society and have implications for AlQuds/Jerusalem from the unilateral recognition of Israel.

\section{CONCLUSION}

Based on the above exposure it can be concluded several things. First, the history of Al-Quds viewed from the perspective of Judaism, Christianity and Islam shows the 
link between the theological studies of each doctrine with a visible historical journey. In addition, the history of Al-Quds is also filled with the dynamics of struggle of power from the time of the kingdom to the nation state. Second, the world history perspective breaks down the journey of Al-Quds (Jerusalem) from the Proto Kana'an period around 4500-3500 BC, followed by the Neo-Babylonian period, the Roman period, the Byzantine period, the Rashidun, Umayyad, and Abbasid periods, Fatimids until the decline of the Ottoman period and the transfer of the city into the British mandate in 1917. The city was once destroyed twice, besieged 23 times, attacked 52 times, and contested 44 times. Third, the international law perspective indicates that the countries in the world shows the surveillance towards Al-Quds through international cooperation agencies from the establishment of UN Resolution in 1947 to the U.S. claim on Jerusalem's as the capital of Israel in 2017. The above sequence of events shows that Israel the United States based on international law perspective can not make unilateral claims against Al-Quds (Jerusalem).

\section{REFERENCES}

[1] United Nations. The Status of Jerusalem. Accessed from http://www.un.org/Depts/dpi/palestine/ch12.pdf.

[2] Ibid.

[3] M. Alaa Mandour. (2017). Jerusalem: A Tale of A City. Journal of Islamic Architecture Vol. 4 No. 4. Accessed from http://ejournal.uinmalang.ac.id/index.php/JIA/issue/view/439.

[4] Martin H. Pohlmann. Embracing a vision of the New Jerusalem to impact on life and society. Accessed from: https://indieskriflig.org.za/index.php/skriflig/article/view/1854/3066.

[5] Andi Satrianingsih and Zaenal Abidin. (2016). Sejarah Zionisme dan Berdirinya Negara Israel.. Jurnal Adabiyah Vol. 16 No. 2. Accessed from: http://journal.uinalauddin.ac.id/index.php/adabiyah/article/view/1764.

[6] Martin H. Pohlmann. loc. cit.

[7] Fuad Muhammad Shibel. (1970). Masalah Jahudi International, terj. Bustami A. Gani dan Chatibul Umam. Jakarta: Bulan Bintang. Accessed from: http://library.um.ac.id/free-contents/index.php/buku/detail/masalah-yahudiinternasional-fuad-muhammad-shibel-diterjemahkan-oleh-h-bustami-a-ganichatibul-uman-19087.html.

[8] Lee I. Levine. Jerusalem in Jewish history, tradition, and memory. Accessed from: http://aleph.nli.org.il/nnl/rmb01/20/79/40/00/RMB01.000472079.html.

[9] Yaron Z. Eliav. The Temple Mount in Jewish and early Christian traditions in Tamar Mayer and Suleiman Ali Mourad (ed.). Jerusalem: Idea and reality. Accessed from http://sites.lsa.umich.edu/yaroneliav/wpcontent/uploads/sites/43/2014/02/EliavJerusalemArticle.pdf.

[10] Sabda Web. Raja-Raja - Alkitab Terjemahan Baru. Accessed from: http://www.sabda.org/sabdaweb/bible/chapter/?b=12\&c=23.

[11] Kisah-Kisah Perjanjian Baru. Accessed from: https://www.lds.org/manual/newtestament-stories?lang=ind. 
[12] Paula Fredrisken. The Holy City in Christian Thought. Accessed from: http://www.bu.edu/religion/files/pdf/The-Holy-City-in-Christian-Thought.pdf.

[13] Misri A. Muchsin. (2015). Palestina dan Israel: Sejarah, Konflik dan Masa Depan. Miqot: Jurnal Ilmu-ilmu Keislaman Vol. 39 No. 2. Accessed from http://jurnalmiqotojs.uinsu.ac.id/index.php/jurnalmiqot/article/view/32.

[14] Nader Qasem. (2014). Al Quds Fi Al Kitaabah As Syi'riyyah At Tanaashiyyah 'inda Samiih Al Qaasim. Palestine: An-Najah National University.

[15] Al-Qur'an Surah Al-Isra. Accessed from: https://quran.com/17/1.

[16] Al-Qur'an Surah Al-Baqarah Verse 144. Accessed from: https://quran.com/2/144.

[17] Jawahir Thontowi. (2001). Yerusalem Tanah Suci Agama Samawi dalam Perspektif Hukum dan Perdamaian. Jurnal Hukum Ius Quia Iustum Vol. 8 No. 18. Accessed from http://journal.uii.ac.id/index.php/IUSTUM/article/view/4857.

[18] Ora Limor. Sharing Sacred Space: Holy Places in Jerusalem Between Christianity, Judaism, and Islam. Accessed from: http://www.openu.ac.il/Personal_sites/download/Ora-Limor/Limor-SharingSacred-Space.pdf.

[19] Ajat Sudrajat. Jerusalem: Kota dalam Sengketa. Accessed from http://staffnew.uny.ac.id/upload/131862252/penelitian/Jerusalem++ Kota+dalam+Sengketa.pdf.

[20] Institution of the Innovatory Jurisprudent. Al-Quds, a historical overview and the significance of Al- Quds Day. Accessed from: http://english.bayynat.org.lb/islamicinsights/insight_AlQuds.htm.

[21] Al-Jazeera. The history of Jerusalem . Accessed from http://www.aljazeera.com/archive/2003/12/20084916191675293.html.

[22] Tempo. Begini Sejarah Perebutan Yerusalem Sejak Ribuan Tahun Lalu. Accessed from https://dunia.tempo.co/read/1043200/begini-sejarah-perebutan-yerusalemsejak-ribuan-tahun-lalu.

[23] United Nations. The Status of Jerusalem. loc.cit.

[24] Ibid.

[25] Ibid.

[26] Ibid.

[27] Ibid.

[28] Ibid.

[29] Ibid.

[30] Ibid.

[31] White House. Statement by President Trump on Jerusalem. Accessed from https://www.whitehouse.gov/briefings-statements/statement-president-trumpjerusalem/.

[32] Al-Jazeera. Five key developments since Trump's Jerusalem move. Accessed from http://www.aljazeera.com/news/2017/12/key-developments-trump-jerusalemmove-171214135132799.html.

[33] Ibid.

[34] Al-Jazeera. UN Jerusalem resolution: How each country voted. Accessed from http://www.aljazeera.com/news/2017/12/jerusalem-resolution-country-voted171221180116873.html.

[35] BBC. Jerusalem: UN resolution rejects Trump's declaration. Accessed from http://www.bbc.com/news/world-middle-east-42446027. 